\title{
Dorota Jarząbek-Wasyl
}

Uniwersytet Jagielloński

\section{W RYTMIE KÓL}

\section{Zapiski Heleny Modrzejewskiej z amerykańskiego tournée w 1893}

Był to trzynasty tour Modrzejewskiej w Ameryce, trwający od października 1892 do połowy marca 1893 i obejmujący północno-wschodni rejon kraju. ${ }^{1}$ Nowy Rok zastał trupę w Eau Claire w Wisconsin. Nad „przejrzystą wodą”, jak brzmiała nazwa osady, Modrzejewska zaczęła prowadzić regularne notatki w kalendarzu. Zakupiony specjalnie w tym celu „Excelsior Diary for 1893” miał format idealny dla amatorów podróży i travel writing: elegancki tomik był nieduży, a przy tym pojemny, na każdy dzień przypadała w nim osobna stronica. ${ }^{2}$ Wewnątrz okładki znalazł się nawet drobiazgowy informator amerykańskiej Poczty Krajowej (klasy i ceny przesyłek) - to nie przypadek, bowiem pisanie listów oraz prowadzenie dziennika stało się główną rozrywką Madame Modjeskiej, której kalendarz ten towarzyszył jako kanwa zapisków od 1 stycznia do 16 lutego 1893 roku.

Amerykański diariusz Modrzejewskiej jest znany historykom teatru, był nawet drukowany i parafrazowany - nie doczekał się jednak ani osobnej analizy, ani, co ważne, rzetelnego i wiernego wydania $\mathrm{z}$ odpowiednim aparatem krytycznym, na jakie zasługuje. Diariusz Modrzejewskiej stanowi wyjątkowe świadectwo jej zawodowego trudu oraz, w nie mniejszym stopniu, przyczynek do refleksji o autobiografii teatralnej, a ściślej mówiąc o genezie i specyfice diariusza teatralnego.

1 J. Szczublewski, Żywot Modrzejewskiej, Warszawa 1977, s. 541-542. Do 1907 Modrzejewska miała odbyć jeszcze drugie tyle objazdów, była więc u szczytu popularności i zarazem w najintensywniejszym okresie swej aktywności zawodowej w Stanach Zjednoczonych. Zob. B. Holmgren, Starring Madame Modjeska. On Tour in Poland and America, Bloomington and Indianapolis 2012 (zwłaszcza rozdział On the American Road).

2 Ten typ kalendarzy był znany w Anglii i Stanach Zjednoczonych od końca XVIII wieku, najpierw w wersji ekskluzywnej, dla elitarnego odbiorcy, następnie wydawany na masową skalę i chętnie wybierany na prezent gwiazdkowy. Zob. E. Kolinko, Dziennik Heleny z Wolskich Krukowieckiej (1831-1833) w perspektywie diarystyki kobiecej epoki, praca doktorska napisana pod kierunkiem prof. dr hab. Elżbiety Z. Wichrowskiej, Wydział Polonistyki UW, Warszawa 2019, maszynopis, s. 60-61. 


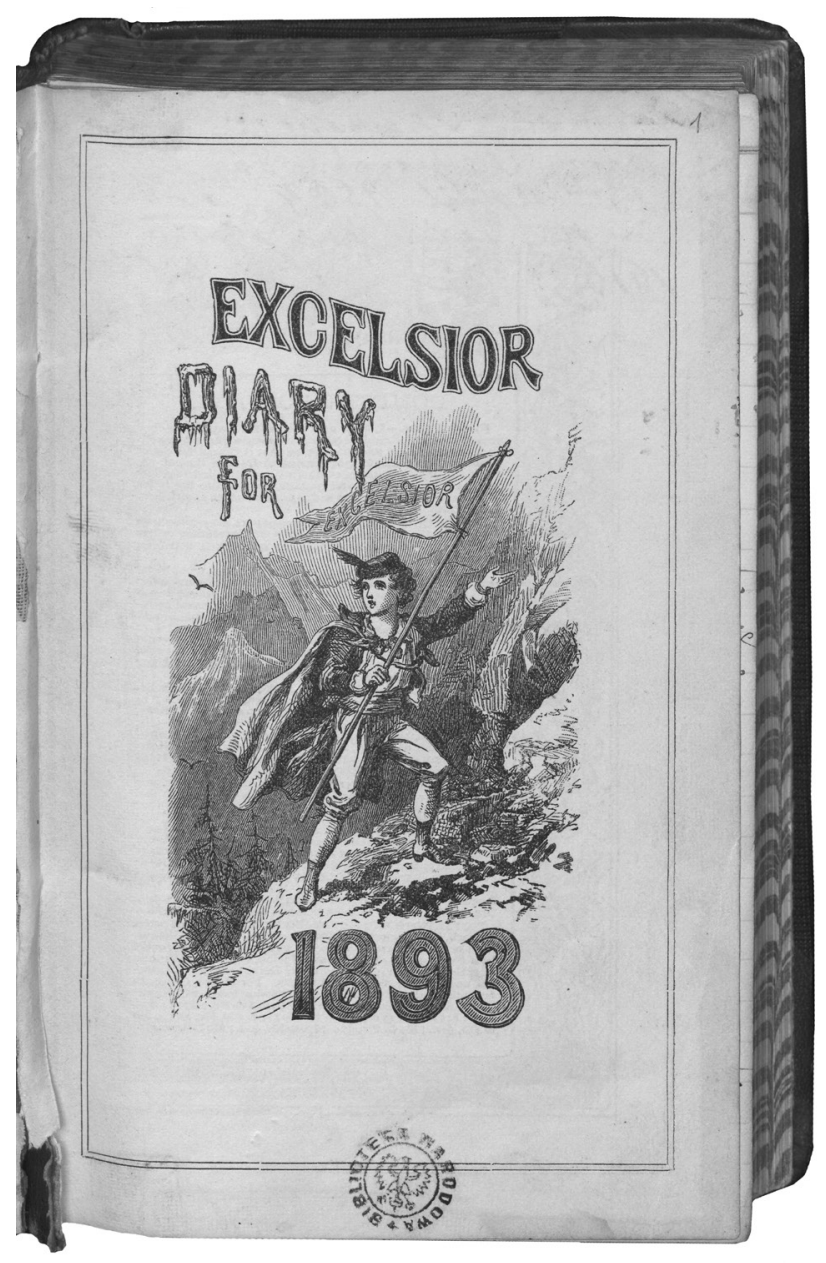

Karta tytułowa „Excelsior Diary for 1893” Heleny Modrzejewskiej. Biblioteka Narodowa

Edycja tego rodzaju dokumentów jest potrzebna również dlatego, że zachowało się ich tak niewiele. Jeśli anglosascy badacze mają do dyspozycji kilka tysięcy autobiografii (nie licząc niepublikowanych listów i dzienników) aktorskich ${ }^{3}$, na polskim gruncie ich liczba nie przekracza trzystu tekstów. ${ }^{4}$

3 Zob. T. Postlewait, Autobiography and Theatre History, [w:] Interpreting the Theatrical Past. Essays in the Historiography of Performance, ed. T. Postlewait, B. A. McConachie, Iowa City 1989, s. 252.

4 Katarzyna Kręglewska, autorka najświeższej i pod wieloma względami pionierskiej pracy o autobiografistyce i biografistyce teatralnej doliczyła się 270 tekstów, zob. Polskie pamiętniki teatralne. Teoria - historia - teksty, Gdańsk 2018, s. 15. 
Już na pierwszy rzut oka staje się jasne, że diarystka wykorzystała pewien istniejący szablon, związany nie tylko z „gotową” formułą drukowanego kalendarza. Dziewiętnastowieczni aktorzy chętnie opracowywali kalendaria swoich występów (stacjonarnych lub wędrownych) łącząc model kroniki, itinerarium oraz wykazu (wyliczenia) ról. Na przykład Alojzy Żółkowski, pierwszy komik Teatrów Warszawskich, wedle słów samej autorki Wspomnień $i$ wrażeń:

Spisywał swoje pamiętniki w zeszytach szkolnych oprawionych w biały błyszczący papier z obfitą czerwono-złotą ornamentyką. Niekiedy znowu używał małych albumowych książeczek, jakby na wiersze albo imieninowe pamiętniki.

Oto kilka zapisków wielkiego aktora. Tytuły sztuk, w których grał, wypisane są ozdobnie, dużymi literami, czerwonym atramentem; reszta pismem drobnym i atramentem zwykłym. [...]

„Spisek dzieł dramatycznych granych w Teatrach - Wielkim, Rozmaitości i Letnim w r. 1871 Alojzego Gonzagi Żółkowskiego.

\begin{tabular}{|l|l|l|}
\hline 1. Sobota & $\begin{array}{l}\text { T. W. Po raz trzeci tragedia Hamlet } \\
\text { T. R. Antreprener. Wesele w Ojcowie }\end{array}$ & Poszło dobrze. Chwała Bogu! \\
\hline 2. Niedziela & $\begin{array}{l}\text { T. W. Flick i Flock } \\
\text { T. R. Ja, czyli Samoluby }\end{array}$ & $\begin{array}{l}\text { Świetnie! Chwała } \\
\text { Bogu! Wywoływano 6-kroć }\end{array}$ \\
\hline
\end{tabular}

$[\ldots] "$

Chociaż ten dziennik może się wydawać humorystyczny, to jednak niemal religijna cześć, którą on oddaje faktowi uznania przez publiczność, świadczy o tym, jak bardzo owego uznania pragnął i jak rzetelnie sobie na nie zapracowywał. Wiele prostoty i braku zarozumiałości jest też w wykrzyknieniu: „Chwała Bogu!”. Wskazuje on na niepokój, a potem na wdzięczność za wykonaną i sowicie wynagrodzoną pracę. ${ }^{5}$

Ukazując amerykańskim czytelnikom sekretne zapiski polskiego komika, Modrzejewska starała się taktownie zrównoważyć dwa biegunowo różne odczucia. Z jednej strony rozbawienie kuriozalną pedanterią Żółkowskiego, z drugiej - zrozumienie dla jego motywacji. A pojmowała je dobrze, ponieważ diariusz z 1893 niemal do złudzenia przypomina, przynajmniej w incipitach, metodę Żółkowskiego! To jeden kalejdoskop dat, potem nazw miejsc, tytułów sztuk oraz informacji o frekwencji i reakcji publiczności. Teatr jest więc na przemian ,pusty” lub ,przepełniony” (,wyprzedany”), a przyjęcie dobre lub nieświetne. Ponad trzy lata od śmierci warszawskiego komika, Modrzejewska z tą samą chciwością rejestrowała brawa, śmiechy, aplauz widowni. Zapisywała, niemal tak samo gorliwie, bilans artystyczno-finansowy przedstawień, bo „wskazuje on na niepokój, a potem na wdzięczność za wykonaną i sowicie wynagrodzoną pracę". Dziennik Modrzejewskiej jest jednak czymś więcej niż tradycyjną kroniką występów scenicznych w postaci znanej z polskiego gruntu, a w każdym razie dostarcza znacznie więcej

\footnotetext{
5 H. Modrzejewska, Wspomnienia i wrażenia, przekł. M. Promiński, Kraków 1957, s. 213-214.
} 
informacji dotyczących zarówno wewnętrznego samopoczucia autorki, jak i zewnętrznych okoliczności - rzeczywistości tournée. ${ }^{6}$

\section{OPOWIEŚĆ Z DROGI}

O swoich wyprawach po Ameryce Modrzejewska pisała co najmniej na dwa sposoby: nieco inaczej w prywatnych notatkach (w tym w dzienniku), a inaczej w listach adresowanych do osób niewtajemniczonych w realia aktorskiej peregrynacji. Zacznijmy od tego drugiego przykładu, pochodzącego z okresu omawianej zimowej ,tury”:

Nasze dni upływają w ten sposób:

O wpół dziewiątej budzimy się, ja leżę do dziewiątej - Karolek pije kawę i czyta gazety, a w nich wszystkie recenzje o mnie. O dziesiątej przychodzi młody człowiek, aby wycinki z gazet robić. Karolek musi z nim gadać - raz dać mu niektóre listy do odpowiedzi, które dyktuje czasem, następnie przychodzą nasi agenci i z nimi odbywają się rachunki, plany podróży - rozstrzygają się wątpliwości co do cen kolejowych, transportu lub wartości pewnych teatrów, godzin wyjazdu, ekstra przedstawień etc., etc. To zabiera zwykle całe przedpołudnie. Przez ten czas ja idę na próbę lub się w domu uczę często szyję takie rzeczy na scenę, których nie chcę nikomu powierzyć. Naścia zaś jest w teatrze zajęta rozpakowaniem lub zapakowaniem sukien moich i statystek, bo chociaż mam zwykle jedną jeszcze garderobianą, jednak ledwie dadzą sobie rady, tyle jest naprawiania i szycia przy tych pannach, które się na chwilę ukazują jako damy dworu lub wieśniaczki. Damy dworu są zwykle bardzo brudne i nieporządne, a suknie z siebie zdzierają w pośpiechu, jak skórę z ciała, i drą wszystko niemiłosiernie.

Po krótkim obiadku Karolek zasiada do korespondencji lokalnej (ludzie tu ogromnie dużo piszą i lubią pisywać), ja zaś muszę albo przyjmować, albo jeździć z wizytami - a najczęściej zamykam się w pokoju i pracuję. O piątej pijemy herbatę - ja czasem się zdrzemię - a w pół do siódmej idę do teatru. Tak schodzi dzień za dniem, nawet czasu nie mamy na czytanie, tylko tyle, co go jest przed zaśnięciem.?

List ten pochodzi z etapu nieco dłuższego postoju w Chicago w grudniu 1892, a adresatka - Anna Chłapowska - otrzymała niewątpliwie obraz wyidealizowany, w którym amerykańscy podróżnicy zachowują regularne mieszczańskie nawyki. W rzeczywistości, gdy tylko Modrzejewska wyruszała w dalszą drogę, w ten sielski klimat wciskał się niemiłosierny pośpiech, nieprzewidywalność, nieregu-

6 Celowo rezygnuję $\mathrm{w}$ analizie dokumentu z perspektywy feministycznej (kulturowych badań diarystyki kobiecej), choć niewykluczone, że ujawni ona dodatkowe aspekty. Na tym etapie jednak byłaby to optyka zbyt zawężona. W teatralnych dziennikach z „trasy”, między tekstami kobiet i mężczyzn nie ma aż takich różnic. Sam autograf Modrzejewskiej stanowi nie tyle zapis z podróży (jak niekiedy się go przedstawia), ile dziennik występów w trakcie podróży zawodowo-artystycznej, a więc specyficzny gatunek notatek związanych z profesją aktorską i stylem pracy w wędrownych trupach. Diariusz Modrzejewskiej z 1893 zainteresował ostatnio badaczkę intymistyki kobiecej XIX wieku, Emilię Kolinko. Przedrukowała ona sześć stron z autografu, i krótko skomentowała charakter rękopisu, dochodząc do rozczarowujących (ją samą) wniosków. Zob. E. Kolinko, op. cit., s. 60-61.

7 Korespondencja Heleny Modrzejewskiej i Karola Chtapowskiego 1887-1914, oprac. A. Kędziora, E. Orzechowski, Kraków 2015, t. 2, s. 166. 
larne pory odjazdu i przyjazdu, sen do wtóru turkoczących kół wagonu... Także formalny charakter zapisków ustępował pod presją bezustannego podróżowania - krótkie zdania, mniej wycyzelowane stylistycznie, powtórzenia słów, składniowe potknięcia, skróty - to językowa faktura tych notatek. Dlatego bardziej wiarygodnym (choć również nie do końca, o czym będzie jeszcze mowa) źródłem do poznania atmosfery wypraw Modrzejewskiej wydaje się dziennik.

January, Saturday 14. 1893

Henryk ósmy. Matinée.

Makbet - wieczór.

Teatr pełny, chociaż nie tak jak pierwszego wieczoru.

Między przedstawieniami mieliśmy na obiedzie Mrs. Winslow, jej męża i Lulu.

Czas szybko ubiegł przy ożywionej i inteligentnej rozmowie, dopiero przed samą ósmą stawiłam [się na czas $]^{8} \mathrm{w}$ teatrze, ale byłam gotowa na czas.

Moja scena snu wywołała ogromne oklaski. Skinner za Makdufa także był przyjmowany z entuzjazmem. Lane był troszkę niepewny w Makbecie, ale zresztą wszystko dobrze poszło. Jestem zmęczona. Wyjeżdżamy po teatrze, aby się widzieć z Rudolfem w Chicago.

Jak większość amerykańskich kontraktów objazdowych, tak i ten w sezonie 1892/93 uzgodniono w Nowym Jorku. Techniczno-organizacyjną strategię brał na siebie zatrudniony przez artystkę menedżer. ${ }^{9}$ To on czuwał nad rezerwacją obiektów teatralnych i hoteli, sprzedażą biletów, reklamą oraz transportem scenicznych utensyliów (dekoracji, kostiumów). Tak skoordynowana i zabezpieczona podróż nie była wcale łatwa, zważywszy na ówczesne środki komunikacyjne oraz na fakt, jak duże odległości - geograficzne i cywilizacyjne dzieliły aktorów od potencjalnych widzów.

W sezonie 1892/93 trupa Modrzejewskiej przemieszczała się specjalnie wynajętym wagonem kolejowym. Wyruszano w drogę albo późno w nocy (po wieczornym spektaklu), albo wczesną porą, nad ranem. W większych ośrodkach, w których towarzystwo bawiło kilka dni (np. Milwaukee, Minneapolis, Detroit, Baltimore) Modrzejewska rezerwowała sobie niezmiennie dwie przyjemności: nocleg w hotelu i... kąpiel. W lutym 1893 donosiła przyjaciółce, że „podczas tego koczowniczego życia, rzadko mogę znaleźć chwilę odpoczynku i nawet jeśli już ją znajdę, zwykle jest ona wypełniona bólem głowy i snem". ${ }^{10}$

W sumie od początku 1893 przez pięćdziesiąt dni Modrzejewska odwiedziła wraz z zespołem północne stany Minnesota, Wisconsin, Michigan, okrążyła wielkie jezioro Michigan i „zahaczyła” o stany: Indiana, Ohio, Maryland, Kentucky. Zagrała 44 razy. W dzienniku padają nazwy 21 miejscowości: po nocnym wyjeździe

8 W nawiasach kwadratowych słowa wykreślone.

9 W sezonie 1892/93 Modrzejewska współpracowała z agentami Frankiem L. Perley’em i Josephem J. Buckley'em. W poprzednich latach jej menedżerami byli m.in.: Harry Sargent (1877), John Stetson (1882), Daniel Frohman (1885-1886), a także mąż Karol Chłapowski (1883-1884).

10 Korespondencja Heleny Modrzejewskiej ..., op. cit., t. 2, s. 171. 
z Eau Claire grupa zatrzymała się na jednodniowe postoje (i występy) w Oshkosh, Madison i Racine (2-4 stycznia); cztery dni bawiono w Milwaukee (5-8 stycznia), by nabrać sił przed podróżą do odległego o pół tysiąca kilometrów Minneapolis w Minnesocie. Po prawie tygodniu spędzonym pół na pół w Minneapolis i pobliskim St. Paul, prosto z teatru wyruszono w drogę do Chicago $(650 \mathrm{~km})$. Tam artystka mogła się chwilę nacieszyć synem i wnukiem (15 stycznia). Między 16 a 26 stycznia grała co dzień w innym ośrodku, odległym na ogół o 150-200 km, spędzając noce przeważnie w wagonie kolejowym. Trasa wyprawy wiodła przez Fort Wayne - Kalamazoo - Michigan - Grand Rapids - Toledo - Jackson Michigan - Chicago - Ann Arbor - Bay City - East Saginaw - Detroit. Trzy dni w Detroit w upragnionym hotelu (26-28 stycznia) były przygotowaniem do długiej wyprawy do Baltimore (ponad $800 \mathrm{~km}$ ). Po niespełna tygodniu w Baltimore (30 stycznia-4 lutego), niedziela 5 lutego znów upłynęła „w drodze”. Od tego momentu w dzienniku pojawiają się tylko tytuły sztuk, a ostatnie wymienione miejscowości to Indianapolis (14 lutego) i Louisville (16 lutego). To tylko cząstka przedsięwziętej podróży, która trwała po ustaniu dziennikowych notatek. ${ }^{11}$

Żelazny harmonogram z góry zakontraktowanych występów w kilkudziesięciu miejscach sprawiał, że podróżnikom zostawało naprawdę niewiele czasu na to, by bliżej poznać odwiedzane ośrodki. Stąd w diariuszu artystki brakuje właściwie bardziej precyzyjnych informacji geograficzno-historycznych lub społecznych, poza takimi, które można uznać za efekt przelotnej, choć mimo wszystko uważnej obserwacji. Atrakcją były przejażdżki po okolicy - ze względu na warunki zimowe odbywające się saniami - oraz piesze peregrynacje. Modrzejewska robiła je, jak można sądzić, nie tylko zaintrygowana przyrodniczym i miejskim otoczeniem, ale zwyczajnie dla higieny i poprawy samopoczucia. Po dobie spędzonej z kilkunastoma osobami w ciasnym wagonie albo też po kilku godzinach siedzenia w przegrzanej bezokiennej garderobie - rozpaczliwie potrzebowała świeżego powietrza. Z perspektywy rekreacyjnej wycieczki na mrozie lub w śniegu, zewnętrzny świat sprowadzał się jednak do podstawowych konturów. Toteż amerykańskie miasteczka jawią się w dzienniku Modrzejewskiej jako ładne lub brzydkie, zadbane lub nie, katolickie lub protestanckie, z ducha francuskie lub niemieckie, pełne ładnych twarzy i postaci lub nieciekawe pod tym względem. Choć obserwacje diarystki są skrótowe i lakoniczne, czasem rozsadzają je humorystyczne pointy ze szczyptą złośliwości w stosunku do Amerykanów i ich obyczajów. Modjeska jest niewątpliwie mistrzynią bonmotu.

Nieco więcej, choć również w oszczędnym stylu, artystka ma do powiedzenia o budynkach teatralnych, w których przyszło jej wystąpić: o garderobie, wystroju sali. Davidson Theatre w Milwaukee przeraził ją ukrytym starannie przed widow-

11 Od połowy lutego do połowy marca 1893 Modrzejewska odwiedziła jeszcze takie miejscowości jak: St. Louis i Kansas w stanie Missouri, Omaha w Nebrasce, Denver i Pueblo w Kolorado, Lincoln w Nebrasce, a w następnych miesiącach Chicago i Boston. Zob. Szekspir Modrzejewskiej, wybór i oprac. A. Kędziora, Kraków 2015, s. 206-207. 
nią, zakulisowym brudem, nie lepiej było w Metropolitan Opera House w Minneapolis, gdzie czekała bezokienna i przegrzana klitka-garderoba. Do wyjątków należał „ładniutki i czysty” Belle City Opera House w Racine. Sporo uwag, jak już powiedziano, dotyczy fizjonomii publiczności, wśród której Modrzejewska nieodmiennie szukała twarzy kobiet, z zainteresowaniem się im przyglądając. ${ }^{12}$ Kobiety-spektatorki stanowiły gwarancję dobrze wychowanej widowni, ich obecność na przedstawieniu była dowodem kształtowania się amerykańskiej klasy średniej z jej potrzebami ekonomicznymi i kulturalnymi. ${ }^{13}$

Od czasu do czasu rutynę tournée oraz tok dziennika przerywały wizyty w zaprzyjaźnionych amerykańskich domach. Trzeba jednak pamiętać, że towarzyskie spotkania, wizyty i rewizyty, wieczory recytacyjne były również nieoficjalną częścią programu tournée, czy wręcz obowiązkiem wędrującej gwiazdy - służyły zjednywaniu miejscowej inteligencji oraz środowiska dziennikarskiego. A więc i prywatność artystki należała w jakiejś mierze do widzów. Jeśli zaś na prowincji amerykańskiej znajdowali się ludzie nieufni wobec sztuki scenicznej, polska artystka mogła ich przekonać do siebie jako dama, uczestniczka kulturalnych wieczorów i charytatywnych przedsięwzięć. Być może z myślą o podejrzliwych purytanach, formułowała tak oto swoje credo:

Mój sukces polega na mojej uczciwości. A poza tym, choć wiem, że to niemodne być poetyczną, są pewne zarodki poezji w mej duszy; wreszcie jestem religijną kobietą. Są pewne postaci, które nie mogą być zagrane przez kobietę, która nie wierzy w Boga. Pierwszym warunkiem sukcesu aktorki jest mieć duszę; potem ładną buzię, zniewalający głos, atrakcyjną osobowość; ale ten warunek jest pierwszy. ${ }^{14}$

Wyprawę trupy Modjeskiej w sezonie 1892/93 wypełniały z grubsza te same czynności, zobrazowane w litanii nawracających jak mantra słów: wyjazd, przyjazd, wagon lub hotel, spacer lub przejażdżka, kąpiel, obiad, garderoba, spektakl, wyjazd, przyjazd, wagon lub hotel, spacer itd. Jednostajność podróży odciska się w notatkach, w ich ściegu, ale i tematyce, wreszcie w przejęzyczeniach: kabina staje się „kajutą” dryfującą przez amerykańskie przestworza. W miarę upływu dni z notatek coraz silniej emanuje poczucie narastającego znużenia (fizycznego i psychicznego), bezwładu, frustracji zaprawionej wisielczym humorem. Dotykamy pulsu aktorskiego stylu życia i pracy. Życie to „nie pachnie różami” i zdecydowanie urąga prawom higieny. „Wagon mi się sprzykrzył, służba nieznośna, kuchnia zawsze ta sama - duszno - gorąco - strasznie! Mam ochotę wyć" - zapisze któregoś dnia Modrzejewska. Trudno się dziwić tym westchnieniom, pamiętając o nadzwyczajnej mobilizacji sił, jakiej wymagał objazd: pięćdziesięciodwuletnia aktorka wychodziła na scenę prawie codziennie, a zdarzało się, że i dwa razy dziennie: rano oraz wieczorem.

12 Twarze w ogóle są ulubionym obiektem obserwacji Modrzejewskiej. „Jakie twarze, taki duch”.

13 Zob. B. Homlgren, op. cit., s. 159.

14 H. Modrzejewska, Artykuly - referaty - wywiady - varia, wybór i oprac. E. Orzechowski, Kraków 2009, s. 130. 
$\mathrm{Z}$ drugiej strony, im bardziej męcząca była owa teatralna wyprawa, tym większe znaczenie zyskiwały w niej odświętne momenty: spotkanie z synem, synową, wnukiem, a potem nowonarodzoną wnuczką w Chicago; listy otrzymane z Polski i czytane dziesiątki tysięcy kilometrów z dala od kraju polskie dzienniki; lektura powieści; wizyta uczonego podróżnika lub francuskiego dziennikarza; odwiedziny na plebanii polskiej w Milwaukee. Historyk i biografista z nadzieją wypatruje tych faktograficznych urozmaiceń, choć wypada przyznać, że większa część podróży z początku 1893 upłynęła pod znakiem zupełnie czego innego: jednostajnej błahości wypadków.

„Zjadłszy śniadanie w łóżku, czytałam przeszło godzinę Kurierki Warszawskie, a następnie ubrawszy się, zabrałam się do szycia chustki dla Maryi Stuart" to notka z 3 stycznia 1893. Scena, w której Maria Stuart-Modrzejewska wyszywa chustkę potrzebną do roli, siedząc w swoim pokoju-wagonie, mogłaby trafić do Studium o Hamlecie Wyspiańskiego. Ale nawet takiej poezji codzienności znajdziemy w dzienniku niewiele. Wypiera ją proza życia. Kto wie, czy poza występami na deskach najróżniejszych teatrów, Modrzejewska nie spędziła najwięcej godzin tamtej zimy na organizowaniu obiadów („najżywotniejszą kwestią w naszym wagonie była sprawa jedzenia" - zapamięta Otis Skinner ${ }^{15}$ ) oraz na... grze w karty. Karty to w końcu nieodzowny towarzysz aktora i pogromca zakulisowej nudy. Dodać do nich można jeszcze domino, choć w Ameryce nie było, jak się zdaje, popularne. Gdy umysł i przemęczone ciało nie pozwalały artystce na nic innego, siadała do wista, pokera, do „starej panny”. Tak wygląda to w dzienniku: w każdej „kajucie” unoszącego się nad amerykańskimi preriami pociągu-arki, wieczorami ,trzaska się" w karty. Grają starzy i młodzi, w tym dziesięcioletni synek Sargentów, prawie gotowy materiał na nowego Butcha Cassidy lub Sundance Kida. Gra też - nie bez przyjemności - Modrzejewska, choć czasem również zżyma się na towarzyszące karcianym seansom kłęby dymu (sama była namiętną palaczką) oraz hałaśliwość graczy. Z dziennika przeziera w końcu jeszcze jedna, nieodłączna strona aktorskiego życia w drodze: wybuchy dziecięcej niefrasobliwości, humoru, sztubackie żarty i zabawy (np. z przenoszeniem iskry przez naelektryzowane ubrania, czym miał się z upodobaniem trudnić Karol Chłapowski). Dopełnieniem obyczajowej warstwy zapisków Modrzejewskiej może być wspomnienie atmosfery tournée pozostawione przez towarzyszącego jej aktora, Otisa Skinnera:

[życie] toczyło się głównie w prywatnym wagonie, a spotykaliśmy się nie tylko stale w teatrze z powodu występów i prób, lecz również w tym małym hotelu na kółkach; tam się mieszkało, jadło, spało na tyle, na ile było to możliwe w całonocnym huku przejeżdżających pociągów i uderzeniach kół na łącznicach - Madame, jej mąż, agent Buckley i ja, a także nieodłączna polska pokojówka Modjeskiej - Naścia. Madame Modjeska z cudownym opanowaniem pełniła honory domu. Nie

15 O. Skinner, Footlights and Spotlights. Recollections of my Life on the Stage, Indianapolis 1924; cyt. za: B. Holmgren, op. cit., s. 201, przekł. - jeśli nie podano inaczej - D. J.-W. 
była to łatwa sprawa nagiąć nastroje i drażliwe humory, ujawniające się z ranną kawą po nieprzespanej nocy, do tak dalekiej intymności, jak stała się naszym udziałem z powodu nieprzeciętnej liczby spożywanych co dzień wspólnie posiłków (najżywotniejszą kwestią w naszym wagonie była sprawa jedzenia), a jednak Modjeska nie traciła spokoju. Gdy zapytałem, czy kiedykolwiek wpadła w gniew, odparła: „Nie zawsze mam dobry nastrój”. „I mnie często zdarzało się tracić cierpliwość dopowiedział pan Bozenta - ale doszliśmy do wniosku, że nie jest dobrze, jeśli oboje w tym samym czasie dajemy się ponieść emocjom. Ustaliliśmy, że jedno z nas może stracić nerwy tylko wtedy, gdy drugie zachowuje spokój”.

- „I to zawsze działa?” - spytałem.

- „Idealnie - zaśmiała się [Modjeska] - proszę zobaczyć, Karolek jest podekscytowany bez przerwy". ${ }^{16}$

\section{AKTOROWIE W PODRÓŻY}

Warto powiedzieć w tym miejscu parę słów o braci artystycznej, z którą współpracowała Modrzejewska. W podróży towarzyszył jej mąż Karol, od czasu do czasu dołączał impresario Joseph Buckley, a grupa aktorska składała się z osób sprawdzonych i świeżo zatrudnionych. Beaumont Smith (ok. 1860-1901) występował z Modrzejewską od 1891, był również reżyserem w jej zespole. Otis Skinner(1858-1942) właśnie od objazdu w 1893 został głównym partnerem scenicznym Madame Modjeskiej na wiele następnych lat. ,Jest obecnie zapewne najbardziej utalentowanym aktorem amerykańskim, wspaniała przed nim przyszłość" - pisał do rodziny w rok później Karol Chłapowski. ${ }^{17} \mathrm{~W}$ czasie tego objazdu Skinner grał m.in. Makdufa w Makbecie oraz Orlanda w Jak wam się podoba (w tej ostatniej roli toczył pojedynek z prawdziwym zapaśnikiem, Williamem Maldoonem, który wspomógł zespół swoją sportową renomą). Debiutująca na scenie Maud Durbin (1872-1936), dwudziestoletnie „dziecko” w zespole, była ulubienicą Modrzejewskiej, a w niedalekiej przyszłości - żoną Skinnera. W 1892 w trupie znalazła schronienie Hannah E. Sargent, porzucona żona pierwszego impresaria Modrzejewskiej. Do zespołu należeli też John A. Lane, Wadsworth Harris, Benjamin G. Rogers, Robert Peyton Carter, Annie Proctor, rekwizytor Kelly/Kelley (tak w zeszycie). Służąca Naścia pomagała w obszywaniu i ubieraniu statystów. Wiadomo więc, że takowych zatrudniano, podobnie jak niewielką grupę muzyków. Wożono również dekoracje i rekwizyty (gdy mający słabość do trunków Kelly nie zadbał o ich transport ze stacji, dochodziło do komplikacji scenicznych, np. Maria Stuart nie miała na czym uklęknąć).

Zespół aktorski został, zwyczajem amerykańskim, tak skonfigurowany, by zapewnić obsadę kilku sztuk, w tym wypadku było ich siedem: Henryk VIII, Makbet, Jak wam sie podoba, Wiele hałasu o nic i Cymbelin Shakespeare'a ${ }^{18}$, Maria

16 Ibidem.

17 Korespondencja Heleny Modrzejewskiej..., op. cit., t. 2, s. 190.

18 Grany w sumie tylko pięć razy na początku objazdu, w dużych ośrodkach (Nowym Jorku, Filadefii i Brooklinie). Zob. Szekspir Modrzejewskiej, op. cit., s. 163. 
Stuart Schillera i Dama kameliowa/Camille Dumasa. Nie bez powodu Modrzejewska zanotowała na odwrocie okładki kalendarza daty urodzin i śmierci Stratfordczyka. Shakespeare był patronem tej wyprawy. W sezonie 1892/93 nowością w repertuarze Modrzejewskiej był Henryk VIII, przedstawiony po raz pierwszy 10 października 1892 w Garden Theatre w Nowym Jorku. ${ }^{19}$ Modrzejewska przygotowywała się do tej premiery bardzo starannie. Poszukiwanie materiałów historycznych, wzorów do kostiumów i detali scenicznych z epoki Tudorowskiej przypominało gromadzenie olbrzymich zapasów na drogę:

Przygotowanie Henryka VIII zajęło mi cztery miesiące - projektowałam stroje paziów i heroldów, meble i rekwizyty, nawet mitry i pastorały biskupów i kardynałów, kubki i sztandary. Uroczyste stroje dla kardynałów odwzorowałam z rycin historycznych. ${ }^{20}$

Premierze towarzyszył również ton artystycznej rywalizacji - w tym samym sezonie swoją wersję Henryka VIII obiecywał amerykańskiej publiczności Henry Irving. Polska artystka i antreprenerka proponowała spektakl z silną rolą kobiecą (równoważącą niesympatyczną, jej zdaniem, figurę Henryka) - co już mogło nieść ton polemiczny wobec Irvingowskiej wersji. Ale była to także bezwzględna walka o widza; wobec rozmachu kosztownego przedsięwzięcia Irvinga, Modrzejewska uzasadniała swoje znacznie skromniejsze plany (mistrzowsko uwodząc reklamowymi szczegółami czytelnika):

Chciałabym to jasno podkreślić - powiedziała w uniesieniu Mme Modjeska - że nie mam zamiaru proponować ,produkcji sztuki”, jak to robi pan Irving. Takie postępowanie jest całkowicie obce artystycznemu credo, które przyjęłam i którego się trzymam. Będziemy mieć, rzecz jasna, nową dekorację i, oczywiście, nowe kostiumy, a reżyserię sztuki starannie przemyślaną i przeprowadzoną w taki sposób, że, jak ufam, zdobędzie aplauz nawet nieuczonej widowni. Nie szukamy jednak widowiskowych efektów, jakkolwiek zatrudnimy około stu statystów do różnych scen; liczymy też na to, że odpowiednio duże wrażenie wywrze scena balu, w czasie której odtańczony będzie autentyczny gawot z czasów Henryka VIII i pojawią się ówczesne pieśni i kompozycje muzyczne. ${ }^{21}$

Modrzejewska była autorką inscenizacji sztuki (podjęła m.in. istotną decyzję pominięcia ostatniego aktu), sama zaś zagrała Katarzynę Aragońską, umieszczając tę rolę w katalogu portretów „czystej kobiecości” obok takich Szekspirowskich postaci jak Imogena i Izabela. Zainteresowanie postacią królowej Katarzyny wspierał dodatkowo, w argumentacji artystki, autorytet takich interpretatorów jak Samuel Johnson. ${ }^{22}$ Warto tu podkreślić jeszcze jeden element tych auto-eksplikacji Modrzejewskiej. To sama artystka ogłaszała w prasie lokalnej - lub zlecała napisanie - artykułów przybliżających historię tworzenia roli i spektaklu. Występ bywał więc obramowany prasowymi relacjami, na przykład 9 grudnia 1892

\footnotetext{
19 Ibidem, s. 206.

20 H. Modrzejewska, op. cit., s. 124.

21 „Milwaukee Sentinel” z 9 XII 1892; cyt. za: B. Holmgren, op. cit., s. 192.

22 H. Modrzejewska, op. cit., s. 131-133.
} 
w „Milwaukee Sentinel” czytelnicy otrzymywali wywiad z artystką, by w styczniu 1893 obejrzeć spektakle i ponownie przeczytać ich podsumowanie w lokalnej gazecie. Do wysiłku artystycznego dochodziła troska o machinę reklamowo-informacyjną, która zapewniała frekwencję.

Dziennik Modrzejewskiej powstał w czasie eksploatowania wymyślonego już i gotowego spektaklu - informacje artystyczne są w nim bardzo oszczędne, rutynowe, splecione z obyczajową tkanką życia w podróży. Interesujące są wszakże obserwacje partnerów prowadzone z perspektywy sceny. Modrzejewska notowała chwile, gdy aktorzy grali w roztargnieniu lub letargu, albo gdy dawali z siebie wszystko - za każdym razem to publiczność oddziaływała na temperaturę i nastrojenie gry. Co ciekawe, zimna lub obojętna publiczność nie musiała jednoznacznie wpływać na dekoncentrację aktorów. Tylko pewien skrajny przypadek kompletnego braku kontaktu między sceną a widownią (który przydarzył się w Toledo) miał taki skutek w abnegacji po jednej i drugiej stronie rampy. Na ogół jednak aktorzy - nawet gdy publiczność zdawała się obojętna na powaby Szekspirowskiej komedii - bawili się sami i sami pławili w żywiole rozgorączkowanej, entuzjastycznej gry.

Zaskakiwać może, jak mało uwagi autorka dziennika poświęca swojej pracy nad rolą. Trudno się temu dziwić - wszystkie role były już wyuczone, a spektakle „ustawione”, i należało jedynie odtworzyć wypracowany schemat działań. A jednak i tu potrzeby aktorki były większe - choć o swoich postaciach napomyka nader lakonicznie, jednak wiele wskazuje na to, że myślała o nich także poza sceną, szukając punktu zaczepienia dla wyobraźni w otaczającym świecie. I tak oto w oczach Modrzejewskiej jedna z jej amerykańskich przyjaciółek - pani Winslow z Saint Paul - wydaje się zadziwiająco podobna do Marii Stuart. Artystka z zainteresowaniem wpatruje się w twarz i oczy Amerykanki, zaintrygowana tym nagłym zestawieniem roli i znajomej osoby. Podobne momenty artystycznej epifanii są, przyznajmy, rzadkie w dzienniku. To nie nauka roli ani autoanaliza w procesie aktorskiego stwarzania postaci, lecz somatyczny i fizjologiczny rytm życia stał się domeną tych zapisków. Manicure, dobra kolacja, kąpiel dla higieny pracy aktora liczyły się tak samo, jak dobra książka i ożywcza rozmowa. Dlatego Madame Modjeska nie podróżuje z komentarzami do Shakespeare'a ani wielką biblioteką, za to z radością wita przyjazd serdecznej przyjaciółki: panny Freeman.

\section{KIM JEST LOU B. FREEMAN?}

Lou $(\mathrm{Lu})$ B. Freeman określa się w przypisach do korespondencji Modrzejewskiej jednym zdaniem: przyjaciółka artystki, towarzysząca jej w 1890 i 1891 w Polsce, Czechach i Francji. Nie wiadomo, kiedy się poznały. Młoda Amerykanka była związana z Nowym Jorkiem (spokrewniona z lekarzem Louisem Livingstonem Seamanem). Nieźle wykształcona, chyba dość zamożna, znała francuski, 
miała kontakty w Paryżu i, co ważne, nie bała się szmuglowania sukien z paryskich salonów modniarskich do Stanów, co było jedynym sposobem na ominięcie gigantycznych opłat celnych. Znała się na modzie, pomagała Modrzejewskiej w pertraktacjach z krawcowymi. W trakcie zimowej wyprawy w 1892 to w jej rękach spoczywał finalny kostiumowy efekt niejednej kreacji - scenicznej albo wizytowej. Poza tym była inteligentną i namiętną czytelniczką, śledziła nowości wydawnicze, prowadziła - jak na młodą pannę w tamtej epoce przystało - sztambuch z wierszami. Nieobce jej były również pasje artystyczne. ${ }^{23}$ Lu Freeman miała wreszcie niewątpliwie dar zjednywania sobie ludzi. ${ }^{24}$

W dzienniku młoda Amerykanka („Lube”, „Lu”) pojawia się znienacka, zaskakując samą Modrzejewską, choć ta wcześniej sprowokowała jej wizytę listem z 20 grudnia 1892. List ten ukazuje żartobliwy, chaotyczny i wielowątkowy sposób komunikowania się przyjaciółek oraz głębszą naturę tej przyjaźni:

Chciałabym Ci wysłać książkę na Boże Narodzenie albo jakąś pamiątkę, ale tu nie mogę niczego dostać - mam zamiar zacząć robić zakupy w Chicago w przyszły czwartek, jednak ponieważ tam - jak podejrzewam - nie będę miała czasu pisać do Ciebie, zdecydowałam się na wysłanie samego listu - z jednym prezentem tylko - moją nieustającą miłością dla Ciebie.

Wolę to nazwać: przyjaźń, ponieważ słowo: miłość - było nadużywane i źle rozumiane przez ostatnich kilka wieków.

Czy będziesz miała kiedykolwiek dosyć wolnego czasu, by przeczytać ten długi list? Zawsze mi powtarzasz, że nie piszę dosyć - a więc masz.

Moja nowa, droga przyjaciółka wciąż do mnie pisze. Jedno pudło w moim kufrze na kapelusze jest już wypełnione, a oczekuję na więcej. Mam zamiar odpowiedzieć na jej ostatnie siedemnaście listów. Nie sądzisz, że byłby czas to zrobić? ${ }^{25}$

10 stycznia 1893 listy nie były już konieczne. Lu Freeman zjawiła się w pokoju hotelowym Modrzejewskiej w Minneapolis i od tej pory nie odstępowała jej na krok, mieszkała z nią w „kajucie”, w tym samym czasie korzystała z dobrodziejstw kąpieli w hotelu, po Karolu była pewnie pierwszą osobą, którą Madame widziała rano przy sobie i witała zwyczajowym embrassement. Amerykanka dzieliła podróżne trudy zespołu, pomstując na niewygody. Głos $\mathrm{Lu}$ - osoby z zewnątrz, chwilowo obecnej w zespole, wyrażał prawdopodobnie wszystko to, co czuli pozostali członkowie towarzystwa, przeżuwający swoje niezadowolenie w myślach, bo nie wypadało im narzekać. Weredyczka Lu rozładowywała więc napięcia. Również dla samej Modrzejewskiej panna Freeman stanowiła idealną femme de compagnie: jej humor i niesforny charakter, a gdy trzeba delikatność

23 W 1893 aktorka pisała: „Panna Freeman ostatecznie studiuje sztukę i pracuje w studio trzy do czterech godzin dziennie. Ma zamiar studiować anatomię”. Korespondencja Heleny Modrzejewskiej..., op. cit., t. 2, s. 192.

24 W Zakopanem za jej portret zabrał się Stanisław Witkiewicz, a Karol Potkański przekomarzał się z nią po angielsku.

${ }_{25}$ Korespondencja Heleny Modrzejewskiej..., op. cit., t. 2, s. 168. 
i zdrowy rozsądek były nie do przecenienia. W wolnym czasie obie przyjaciółki chodziły po księgarniach, ale też zajmowały się pielęgnacją paznokci. Wreszcie to Lu, o zgrozo, wciągnęła przyjaciółkę, w karciane rozrywki - ,aby jej przyjemność zrobić", Modrzejewska nauczyła się grać w pokera. ${ }^{26}$

Między starszą aktorką a młodą towarzyszką ustaliła się relacja partnerstwa, przyjaźni (pełnej nieustannych sporów i utarczek), ale też wzajemnej troski, czy nawet rodzinnej więzi. Modrzejewska starała się być dla Lu kimś w rodzaju „,matki teatralnej”, usiłowała dyskretnie na nią wpływać, a nawet zrobić z niej „katoliczkę”. Z kolei panna Freeman godziła się na rolę opiekuńczej „córki”. „Dobra Lu była dotąd cały czas przy mnie, pielęgnując mnie jak córka [...] wróci pojutrze, by mi czytać lub zabawiać miłą gadaniną" - pisała Modrzejewska w grudniu 1891 z Filadelfii. ${ }^{27}$ Nieprzypadkowo więc imię panny Freeman tak często pada w dzienniku i nie wyłącznie amerykańska wylewność kazała Modrzejewskiej porównać młodszą przyjaciółkę do „kogoś, kto jest zawsze obecny w moich myślach i żyje w sercach całej rodziny Modrzejewskiej”. ${ }^{28}$

\section{DZIENNIK - Z PERSPEKTYWY GENETYCZNEJ}

Fundamentem dziennika jest skrócony dystans między chwilą przeżytą i momentem zapisu. Diariusz zyskuje w ten sposób nieocenione walory dokumentalne - jego autor może się mylić, ulegać emocjom pod wpływem chwili, mieć zaburzoną percepcję, przekazuje jednak wrażenia nieomal na żywo, nieoczyszczone, często nieocenzurowane, świeże, bo sprzed chwili. Nie znaczy to oczywiście, że jest to pisanie ,automatyczne” bez kontroli i planu - znawcy tematu twierdzą, że dzienniki układane są w głowie i pisane z premedytacją. Niemniej odróżnia je od formy pamiętnika czy autobiografii absolutyzacja „dzisiaj” czy „teraz”, z którym wiąże się tekst zapisu. Co więcej, pisanie jest silnie zrośnięte z życiem, doświadczaniem codzienności - przenika się z egzystencją w sposób trudny nieraz do oddzielenia.

Również w dzienniku Modrzejewskiej widoczna jest ta zatrzymana struktura teraźniejszości, materializuje się tu osobliwe, niekiedy wręcz surrealne odczucie czasu i przestrzeni, jakie miała autorka w długiej, pełnej niewygód i bądź co bądź jednostajnej podróży. Urok tych zapisków jest urokiem prowizorium, szkicu, pospiesznej notatki z ulotnej chwili. Wystarczy popatrzeć na znaki interpunkcyjne: sama kropka nie kończy zdania, po niej następuje myślnik, ogniwo łączące zdanie $\mathrm{z}$ dalszym ciągiem narracji, dzień z kolejnym dniem.

Trzeba przyznać, że omawiany dokument sprawia sporo kłopotów genologicznych i edytorskich. Kryje w sobie również wiele znaków zapytania. Podstawowe

\footnotetext{
26 Ibidem, s. 463.

27 Ibidem, s. 136.

28 Ibidem, s. 169.
} 
pytanie dotyczy celu robienia tych notatek, ale także samego czasu ich powstania, wreszcie stosunku do materii słownej i stylistycznej. Modrzejewska notowała po polsku - co nie jest bez znaczenia, już bowiem akt wyboru nie angielskiej, a polskiej mowy ustanawia dystans do zdarzeń i możliwości ich opisu (zwłaszcza w przypadku przekładu cytowanych w tekście wypowiedzi amerykańskich towarzyszy podróży). Polszczyzna zapisu świadczy zarazem o osobistym, prywatnym wymiarze dziennika, dostępnym tylko dla samej autorki i jej najbliższych. Tekst pisany jest to w czasie przeszłym, to w teraźniejszym - przy czym tu i ówdzie rozsadzają go wtrącenia i uzupełnienia z innej, późniejszej (choć wciąż bliżej nieokreślonej) perspektywy. Niektóre wpisy zostały uzupełnione, jak się zdaje, już po zakończeniu podróży: „nie pamiętam, cośmy grali”, zapisze Modjeska 24 stycznia. Od 2 lutego w kalendarzu widnieją tylko tytuły spektakli lub nazwy miejsc, bez komentarzy - te ostatnie miały zostać dopisane później? Należy więc przyjąć tezę, że aktorka prowadziła dziennik w co najmniej dwóch podejściach, najpierw zostawiając nieregularne notatki z wybranych dni, potem uzupełniając resztę i poprawiając styl całości. To wówczas znikają z tekstu anglicyzmy, niektóre słowa ulegają wygładzeniu (np. ,piekielnie” zamienia się na „strasznie”), znikają też personalia niektórych osób - trwa w najlepsze praca autorskiej cenzury.

Modrzejewska pełni w tym zeszycie dwie nietożsame funkcje: jest autorką tekstu, ale też pierwszą jego czytelniczką. Co nie byłoby zresztą niczym dziwnym, bowiem temu właśnie służy intymistyka:

Diarysta prowadzi dziennik po to, by go później przeczytać. Pisze go, by zachować w pamięci sprawy i chwile, ale również by - kiedyś, później - móc ocenić przeszłość i to, jak się potoczyła. ${ }^{29}$

Sądząc jednak po poprawkach, jakie zawierają diariuszowe notatki Modrzejewskiej (skreśleniach, dopiskach $\mathrm{w}$ interlinii i na marginesie, stylistycznych korektach), w pewnym momencie rozmyślała o ich upublicznieniu (choćby w formie rozległego cytatu z diariuszowych notatek, którą zastosowała we Wspomnieniach $i$ wrażeniach). ${ }^{30}$ Choć do druku tej partii zapisków w oficjalnym pamiętniku Modrzejewskiej nie doszło, to już sama formuła dziennika poddanego retuszowi warta jest uwagi, ponieważ radykalnie zmienia jego status, a nawet, jak sądzą niektórzy - jest przeciwna jego naturze.

Z chwilą gdy wybija północ, autor nie powinien już modyfikować tego, co wpisał pod datą z dnia, który właśnie upłynął. Każda późniejsza ingerencja (dodawanie tekstu, usuwanie, zmiany w jego układzie, zastępowanie jego fragmentów) sprawi, że to co napisał, przestanie być dziennikiem,

29 P. Lejeune, Le journal: genèse d'une pratique, „Genesis” $2011 \mathrm{nr} 32$ (Journaux personnels), s. 38, przekł. L. Mazur.

30 Z zamiarem napisania autobiografii nosiła się już od co najmniej dwóch lat: „odzyskam duszę na kilka dni i pamiętnik mój zacznę pisać”, informowała przed Bożym Narodzeniem 1890. Zob. Korespondencja Heleny Modrzejewskiej..., op. cit., t. 2, s. 90. 
a stanie się autobiografią, czymś, co pozwala kreować na nowo przeszłość w świetle teraźniejszości. Wartość dziennika związana jest z autentycznością zapisu, a każda późniejsza zmiana stanowi dla tej autentyczności zagrożenie. Dziennik jest wrogiem autobiografii. O ile ta ostatnia jest ulubionym przedmiotem badań genetycznych, to w przypadku dziennika krytyka genetyczna ma niewielkie pole manewru. Czas na naniesienie ewentualnych poprawek nie przekracza kilku godzin. Dziennik, niczym akwarela, nie znosi retuszu. ${ }^{31}$

Zeszyt Modrzejewskiej nie jest jednak zwykłym przykładem diariusza, bardziej przypomina świadomie konstruowane archiwum życia i pracy (łączące wielogatunkowe cechy: kroniki, pamiętnika, dziennika, notatki), z którego aktorka tworzy zręby przyszłej, potencjalnej autobiografii. Na związany z chwilą zapis dzienny nakładają się późniejsze redakcje i korekty, dziennik pełni więc funkcję przypomnienia, służy rekonstrukcji obrazu z przeszłości, a czasem skutecznie ją uniemożliwia - jak pusta plama w pamięci i pusta karta w kalendarzu. Ostatnią zagadką tego tekstu jest to, że tak raptownie i bez powodu się urywa. Czy to z powodu zmęczenia trasą i braku czasu, czy z innych nieznanych przyczyn, tournée z 1893 w połowie lutego traci wiernego kronikarza. Philippe Lejeune uważa, że dziennik nigdy nie ma zakończenia, jego koniec należy do redaktora, edytora, ale nie do piszącego. Właśnie tak się stało z amerykańskim diariuszem Modrzejewskiej z roku 1893.

$31 \quad$ P. Lejeune, op. cit., s. 30, przekł. L. Mazur. 